\title{
Assessment of health, functioning and disability of a population aged $60-70$ in south-eastern Poland using the WHO Disability Assessment Schedule (WHODAS 2.0)
}

\author{
Agnieszka Ćwirlej-Sozańska', Anna Wilmowska-Pietruszyńska' \\ ${ }^{1}$ Institute of Physiotherapy, Faculty of Medicine, University of Rzeszow, Poland \\ Ćwirlej-Sozańska A, Wilmowska-Pietruszyńska A. Assessment of health, functioning and disability of a population aged 60-70 in south-eastern \\ Poland using the WHO Disability Assessment Schedule (WHODAS 2.0). Ann Agric Environ Med. 2018; 25(1): 124-130. doi: 10.5604/12321966.1228392
}

\begin{abstract}
Introduction. There is a growing number of older people in Poland. This phenomenon results in the need to assess their problems related with functioning in everyday life. This is the first study conducted in Polish society which evaluates the prevalence of disability and limitations in functioning by means of WHODAS 2.0 questionnaire.

Objective. Evaluation of the health, functioning and disability of people aged 60-70 years living in south-eastern Poland. Materials and method. The researched material was a randomly- selected sample of 1,000 inhabitants of south-eastern Poland. The study was conducted by use of direct interviews applying the WHODAS 2.0. For the purpose of statistical analysis, measures of descriptive statistics and non-parametric tests of significance were used.

Results. Limitations in functioning were reported by $67.00 \%$ of participants aged $60-70$ years, including $46.20 \%$ with a mild disability, $14.50 \%$ - moderate, $6.30 \%$ - significant and extremely large disability. The highest level of disability occurred in areas related to participation in social life (mean $=20.77$ ), performing activities of daily living (mean $=17.42)$ and mobility ( $m e a n=17.23)$. A significantly higher level of disability $(p<0.0001)$ was observed among unmarried people, the elderly and those with a greater number of chronic diseases. Higher level of physical activity was associated with lower disability level in the studied population $(\mathrm{p}<0.009)$.

Conclusions. Regarding the studied population, it was found that many health problems become worse over the years. The state of health that deteriorates with age causes limitations in daily functioning, which lead to disability, activity limitations and participation in everyday life. The progressive ageing of the Polish population will cause an increasing demand for medical care and on the social services.
\end{abstract}

Key words

disability, elderly, WHODAS 2.0, Poland

\section{INTRODUCTION}

Changes in the age structure of the global population, related to the ageing of societies, started at the beginning of the $20^{\text {th }}$ century [1]. These changes are particularly relevant in highly developed countries, but are gradually becoming more and more apparent in developing countries as well [2]. They can be mainly attributed to extended life expectancy and reduced mortality rate, as well as a gradually declining birth rate [3]. Europe has the world's largest population of people aged over 65 and the elderly (over 800 years of age), and is the fastest ageing region in the world [4]. In 2006, the European Commission identified ageing as one of the most difficult political issues of the $21^{\text {st }}$ century [5]. According to demographic forecasts, the number of elderly people will continue to grow. In 2015, the world population of people aged over 65 was 901 million, and this number is expected to grow to 2.1 billion by 2050 [6].

In Poland, changes related to population ageing have been observed since the mid-1950s. After World War II, there was a short but significant increase in the birth rate. This

Address for correspondence: Agnieszka Ćwirlej-Sozańska, Staszica 3/5, 35-051 Rzeszów, Poland

e-mail: sozanska@ur.edu.pl

Received: 23 February 2016; accepted: 24 October 2016; first published on December, 2016 caused a demographic explosion, a kind of 'shock wave', the effect of which can now be observed as a significant increase in the number of people aged 60 and over. The situation marked the significant and dynamic entry of Poland into demographic ageing. The higher-birth-rate period of the post-war years ended quite quickly, and the birth rate began to drop systematically, although in a non-linear manner, affected by a cohort factor [7]. Additionally, the process of economic migration of the younger generation, which had its peak directly after Poland joined the European Union, aggravated the scale of the problem [8].

Currently, Poland has already entered the stage of widespread old age. In 2015, the percentage of people aged 60 and over was $22.9 \%$. It is predicted that in 2035 this percentage will reach $31.3 \%$, while in 2050 it will be up to $40.4 \%[9,10]$.

Longer life expectancy and a dynamic increase in the median age in Poland (in 2007 - 37.3, in 2014 - 39, and is expected to reach 47.9 by 2035) are greatly affecting the socio-economic and political situation in Poland [10, 11]. A lack of generation renewal and a drop in the working-age population constitute the basic problem. This subsequently leads to an increase in the coefficient of economic load, which identifies the ratio of the post-working-age population to the working-age population. According to the forecasts, by 2030 , the ratio of people above working age will increase from 30.2 
to 43.7 persons per 100 people of working age and above $[1,11,12]$. If pensions are to be maintained at the present level, it is necessary either to extend the retirement age or to increase the fiscal burden of the working population. The financial burden on the State budget due to growing costs of health care, institutional care, social security, pensions, etc., is also increasing [13].

Increases in the number of disabled people are directly linked to the increased life expectancy and number of elderly people in society [14]. Ageing involves a gradual impairment of life functions and limitation of the body's capacity to adapt to changes in the environment [15]. Hence, physiological ageing is actually a process of the gradual limitation of fitness. Any impairment of the body's structure or function can affect the functions and performance of activities of different complexities in everyday life [16]. Disability is a result of interactions between functional impairment, limited activity and participation, and environmental and personal factors $[17,18]$. However, a person may experience different limitations depending on the environment where he or she lives, or the resources available to them. This means that environmental factors are the key element determining the disability level. A person's functioning depends not only on the state of health, but also on environmental and personal factors [19]. A biopsychosocial model of functioning and disability, which is also covering - besides medical issues - environmental factors, was introduced in 2001 by the World Health Organization (WHO), and was included in the International Classification of Functioning, Disability and Health (ICF). The ICF was the first global classification responding to the need for standardized evaluations, not only from the medical perspective, but also taking into account people's environment and their different potentials [20].

\section{OBJECTIVE}

Considering these issues in the Polish context, their importance and up-to-date character, a cross-sectional study was carried out in 2015 in south-eastern Poland within the Podkarpackie Region. The purpose of the study was to evaluate the level of health, functioning and disability of the population aged $60-70$, as well as the analysis of selected social and demographic factors and their influence on disability occurrence in the studied population. The selected age group is particularly interesting due to the pension reforms that have been implemented in Poland, and the gradual extension of the working age to 67. It is necessary to identify the factors affecting health, functioning and disabilities among people aged 60 and over, in order to develop preventive means influencing preservation and/or improvement their efficiency, capacity and quality of life, and boost the ability to work.

\section{MATERIALS AND METHOD}

The study was carried out on a randomly-selected group of 1,000 people aged 60-70 from among the citizens of the Podkarpackie Region of south-eastern Poland, using interview-questionnaires implemented by the PAPI method (Pen and Paper Interviews - direct interview using a traditional paper questionnaire). The database of PESEL (personal identification numbers) held by the Ministry of Internal Affairs and Administration was used as the sampling frame. The Regional IT Centre and Field Data Bank at the Regional Office of the Podkarpackie Region in Rzeszów, which operates the PESEL database, selected the participants according to the age criteria (people born between 1 January 1944 - 31 December 1954). The group comprised 6,029 people, and from this group the main (basic) study population of 1,000 was randomly-selected; the remaining 5,029 people constituted a reserve population. The selection (drawing) was made using SPSS software, without returning the already selected participants into the envelope. Inclusion criteria were: age 60-70, proper cognitive state (AMTS - abbreviated mental test score $>6$ points) and informed consent. The survey was conducted by professional, trained interviewers at the place of residence of the respondents. In accordance with the Declaration of Helsinki, the participants were informed about the purpose and the procedure of the study and gave their informed consent to participate. The representative nature of the obtained results meant the acquired information could be applied to a large population. The research study was approved by the Bioethical Committee of the University of Rzeszów.

The research tool used in the study consisted of the WHO Disability Assessment Schedule (WHODAS 2.0) and a questionnaire developed by the authors to collect different socio-demographic data about the studied population. The questionnaire contained questions concerning, e.g., health, functioning, and obtained benefits, as well as questions based on health-care services and demographics (e.g., number of people in the household, income level, education, etc.).

The WHO Disability Assessment Schedule (WHODAS 2.0) is a uniform and standardized tool to measure health and disability in different cultures. It was developed based on a comprehensive set of items included in the ICF. The ICF covers every function of a human being at the biological, individual or social level, perceiving disability as a limitation of a function. WHODAS 2.0 is a practical evaluation instrument that can measure health and disability at the population level or in clinical practice. WHODAS 2.0 covers the level of function in the following 6 domains:

- Domain 1: Cognition - understanding and communicating

- Domain 2: Mobility - moving and getting around

- Domain 3: Self-care - hygiene, dressing, eating and staying alone

- Domain 4: Getting along - interacting with other people

- Domain 5: Life activities - domestic responsibilities (5.1), work and school (5.2)

- Domain 6: Participation - joining in community activities [21].

The domains were selected by the WHO experts after a detailed analysis of the available research instruments and the possibility of using them in different cultures. WHODAS 2.0 was developed based on inter-cultural studies conducted in 19 countries [21]. The Polish version of WHODAS 2.0 was translated and adapted for the Polish conditions. The results regarding the relevance and reliability of the Polish version of the tool will be presented in a separate paper.

To calculate the general disability level in each WHODAS 2.0 domain, the following scale was used, according to the ICF [20, 21]: 


$\begin{array}{ll}\text { No disability } & -0-4 \% \\ \text { Mild disability } & -5-24 \% \\ \text { Moderate disability } & -25-49 \% \\ \text { Severe disability } & -50-95 \% \\ \text { Extreme disability } & -96-100 \%\end{array}$

The obtained data were analysed by means of StatSoft, Inc. (2011), STATISTICA (data analysis software system), version 10. For the purpose of statistical analysis, the measures of descriptive statistics and appropriate statistical tests were used: Mann - Whitney U test and the Kruskal-Wallis test, due to the lack of normal distributions of studied features in the individual sub-samples. The level of statistical significance was assumed at $\mathrm{p}<0.05$.

\section{RESULTS}

The study was conducted on the population of 1,000 people aged 60-70, which comprised 562 women and 438 men. The mean age of the studied population was 64.90 (SD - 3.20 years). $45.30 \%$ of the studied population were inhabitants of cities/towns, while $54.70 \%$ lived in the countryside.

Table 1. Sociodemographic characteristics of the studied population

\begin{tabular}{|c|c|c|}
\hline Sociodemographic characteristics $(N=1000)$ & No. (N) & Percentage (\%) \\
\hline \multicolumn{3}{|l|}{ Gender } \\
\hline Female & 562 & 56.20 \\
\hline Male & 438 & 43.80 \\
\hline \multicolumn{3}{|l|}{ Place of residence } \\
\hline City/town & 453 & 45.30 \\
\hline Countryside & 547 & 54.70 \\
\hline \multicolumn{3}{|l|}{ Marital status } \\
\hline Bachelor/spinster & 49 & 4.90 \\
\hline Married & 749 & 74.90 \\
\hline Separated/divorced & 29 & 2.90 \\
\hline Widower/widow & 162 & 16.20 \\
\hline Living with a partner & 11 & 1.10 \\
\hline \multicolumn{3}{|l|}{ Status on the job market } \\
\hline Gainful employment & 70 & 7.00 \\
\hline Self-employed, e.g., own business/farm & 22 & 2.20 \\
\hline Housewife & 20 & 2.00 \\
\hline Retired & 778 & 77.80 \\
\hline Not working (due to poor health) & 36 & 3.60 \\
\hline Not working (due to other reasons) & 25 & 2.50 \\
\hline Annuitant & 30 & 3.00 \\
\hline Other & 19 & 1.90 \\
\hline \multicolumn{3}{|l|}{ Education } \\
\hline Primary & 277 & 27.70 \\
\hline Vocational & 307 & 30.70 \\
\hline Secondary comprehensive & 90 & 9.00 \\
\hline Secondary vocational & 209 & 20.90 \\
\hline Tertiary & 117 & 11.70 \\
\hline \multicolumn{3}{|l|}{ Income per capita/month } \\
\hline Up to $1,000 \mathrm{PLN}^{*}$ & 96 & 9.60 \\
\hline 1,001 PLN-2,000 PLN & 274 & 27.40 \\
\hline 2,001 PLN-3,000 PLN & 150 & 15.00 \\
\hline 3,001 PLN-4,000 PLN & 68 & 6.80 \\
\hline 4,001 PLN and above & 45 & 4.50 \\
\hline No data & 367 & 36.70 \\
\hline
\end{tabular}

"PLN - (Polish zloty) - the official name of the Polish currency
The great majority of the studied population lived in a relationship: marriage (74.90\%) or with a partner (1.10\%). The rest were single people: widows/widowers (16.20\%), bachelors or spinsters $(4.90 \%)$, separated or divorced people $(0.50 \%$ and $2.40 \%$, respectively). As much as $77.80 \%$ lived from their pension, while only $9.20 \%$ were professionally active. The majority of the studied population had vocational (30.70\%) and primary $(27.70 \%)$ education, followed by secondary vocational $(20.70 \%)$, tertiary $(11.40 \%)$ and secondary comprehensive $(9.00 \%)$. The majority of the studied population (who answered the question regarding income) represented the group with a monthly income per capita in the household ranging from 1,001 - 2,000 PLN.

Table 2 presents the most common diseases in the studied population. Only diseases diagnosed by a physician were taken into consideration.

Table 2. Prevalence of diseases in the studied population

\begin{tabular}{|c|c|c|}
\hline Disease & $\begin{array}{c}\text { No. of people } \\
\text { with a disease } \\
\mathrm{N}\end{array}$ & $\begin{array}{c}\text { Percentage of } \\
\text { people with a } \\
\text { disease } \\
(\%)\end{array}$ \\
\hline Hypertension & 510 & 51.00 \\
\hline Lumbar spine pain syndromes & 415 & 41.50 \\
\hline Degenerative diseases of the spine & 390 & 39.00 \\
\hline Degenerative disease of peripheral joints & 333 & 33.30 \\
\hline Cervical spine pain syndromes & 312 & 31.20 \\
\hline Thoracic spine pain syndromes & 246 & 24.60 \\
\hline Rheumatism & 239 & 23.90 \\
\hline Coronary diseases & 238 & 23.80 \\
\hline Diabetes & 186 & 18.60 \\
\hline Atherosclerosis & 140 & 14.00 \\
\hline Allergy & 139 & 13.90 \\
\hline Severe headaches (migraine) & 138 & 13.80 \\
\hline Thyroid conditions & 116 & 11.60 \\
\hline Osteoporosis & 113 & 11.30 \\
\hline $\begin{array}{l}\text { Heart attack and chronic consequences } \\
\text { of heart attack }\end{array}$ & 94 & 9.40 \\
\hline Renal diseases & 88 & 8.80 \\
\hline Urinary incontinence & 72 & 7.20 \\
\hline Depression & 71 & 7.10 \\
\hline Gastric and duodenal ulcerative disease & 57 & 5.70 \\
\hline Diseases of the prostate gland (men) & 56 & 5.60 \\
\hline Chronic respiratory diseases & 55 & 5.50 \\
\hline Asthma & 53 & 5.30 \\
\hline Neoplastic disease & 46 & 4.60 \\
\hline Stroke & 39 & 3.90 \\
\hline Cirrhosis & 23 & 2.30 \\
\hline
\end{tabular}

Circulatory diseases (in particular: hypertension - 51.00\%, coronary disease $-23.80 \%$ ), spine pain syndromes (lumbar spine $-41.50 \%$, cervical spine $31.20 \%$ ), degenerative diseases of peripheral joints (33.30\%), and rheumatism (23.90\%) prevailed in the studied population.

Only $33.00 \%$ of the studied population) were fully fit with no limitations in their functioning. The majority of the 
Table 3. Disability level of the studied population aged $60-70(N=1,000)$

\begin{tabular}{lcc}
\hline Disability level & No. $(\mathrm{N})$ & Percentage $(\%)$ \\
\hline No disability & 330 & 33.00 \\
\hline Mild disability & 462 & 46.20 \\
\hline Moderate disability & 145 & 14.50 \\
\hline Severe disability & 62 & 6.20 \\
\hline Extreme disability & 1 & 0.10
\end{tabular}

studied population (46.20\%) had mild disability, in $14.50 \%$ disability was moderate and in $6.20 \%$ it was severe. Only one person was found to have an extreme level of disability.

Table 4. Mean results of disability measurements in each domain

\begin{tabular}{lccccccc}
\hline $\begin{array}{l}\text { Disability } \\
\text { domains }\end{array}$ & $\begin{array}{c}\text { Mean } \\
\text { SHODAS 2.0 }\end{array}$ & SD & $\begin{array}{c}\text { None } \\
(\%)\end{array}$ & $\begin{array}{c}\text { Mild } \\
(\%)\end{array}$ & $\begin{array}{c}\text { Moder- } \\
\text { ate } \\
(\%)\end{array}$ & $\begin{array}{c}\text { Severe } \\
(\%)\end{array}$ & $\begin{array}{c}\text { Ex- } \\
\text { treme } \\
(\%)\end{array}$ \\
\hline $\begin{array}{l}\text { Domain 1: } \\
\text { Cognition }\end{array}$ & $\begin{array}{c}9.37 \\
(8.31-10.42)\end{array}$ & 17.08 & 60.50 & 23.70 & 10.70 & 5.10 & 0.00 \\
\hline $\begin{array}{l}\text { Domain 2: } \\
\text { Mobility }\end{array}$ & $\begin{array}{c}17.23 \\
(15.70-18.76)\end{array}$ & 24.68 & 47.30 & 24.80 & 12.80 & 14.40 & 0.70 \\
\hline $\begin{array}{l}\text { Domain 3: } \\
\text { Self-care }\end{array}$ & $\begin{array}{c}5.37 \\
(4.45-6.29)\end{array}$ & 14.79 & 81.00 & 11.10 & 4.50 & 2.80 & 0.60 \\
\hline $\begin{array}{l}\text { Domain 4: } \\
\text { Getting along }\end{array}$ & $\begin{array}{c}11.63 \\
(10.54-12.73)\end{array}$ & 17.66 & 50.20 & 30.40 & 13.10 & 6.10 & 0.20 \\
\hline $\begin{array}{l}\text { Domain 5: Life } \\
\text { activities }\end{array}$ & $\begin{array}{c}17.42 \\
(15.78-19.06)\end{array}$ & 26.36 & 56.20 & 15.80 & 12.00 & 13.20 & 2.80 \\
\hline $\begin{array}{l}\text { Domain 6: } \\
\text { Participation }\end{array}$ & $\begin{array}{c}20.77 \\
(19.47-22.08)\end{array}$ & 21.03 & 22.60 & 41.30 & 24.20 & 11.30 & 0.60 \\
\hline $\begin{array}{l}\text { Total } \\
\text { WHODAS 2.0 } \\
\text { result }\end{array}$ & $\begin{array}{l}14.44 \\
(13.38-15.51)\end{array}$ & 17.17 & 33.00 & 46.20 & 14.50 & 6.20 & 0.10 \\
\hline
\end{tabular}

The mean disability level measured with the WHODAS 2.0 (scale $0-100)$ was 14.44 (SD - 17.17). Disability was most frequently observed in the domain related to life activities (mean - 20.77; SD - 21.03). Activity in the local community, overcoming barriers and obstacles in the external environment, and other problems were evaluated in relation to sense of self-dignity.

The second area in terms of the mean disability level, was noted within problems with performing activities of daily living (mean - 17.42; SD - 26.36). Regarding this field, difficulty was rated in performing daily activities associated with the maintenance of the household, such as cooking, cleaning, shopping, caring for others and for personal belongings.

The third domain in terms of disability occurrence was the area concerned with mobility (mean - 17.23; SD - 24.68). In this section, activities such as standing, moving around the house, going out and walking for longer distances were rated.

Problems related to personal hygiene, getting dressed, eating and staying alone were the least frequent in the studied group (mean - 5.37; SD - 14.79).

No relationship between disability and gender, place of residence, education and income was observed in the studied population. A significant relationship $(\mathrm{p}<0.001)$ was observed between disability and marital status, age and number of diseases in the population. Single people demonstrated a significantly higher disability level compared to people living in a relationship. A higher disability level was
Table 5. Sociodemographic factors and disability in the studied population

\begin{tabular}{lcc} 
Sociodemographic characteristics & Mean WHODAS 2.0 score $(95 \% \mathrm{Cl})$ & $\mathrm{p}$ \\
\hline Gender & $14.60(13.24-15.96)$ & 0.189 \\
\hline Female & $(12.55-15.95)$ & \\
\hline Male & & \\
\hline Age & $12.10(10.79-13.41)$ & $<0.001$ \\
\hline $60-65$ years & $17.56(15.83-19.29)$ & \\
\hline $66-70$ years & &
\end{tabular}

\section{Place of residence}

\begin{tabular}{lcc}
\hline City/town & $14.76(13.16-16.36)$ & 0.364 \\
\hline Countryside & $(12.76-15.62)$ & \\
\hline
\end{tabular}

Marital status

\begin{tabular}{lll}
\hline Married/living with partner & $13.37(12.18-14.55)$ & $<0.001$ \\
\hline Single & $17.87(15.52-20.22)$ & \\
\hline Education & & \\
\hline Primary & $15.26(12.97-17.55)$ & 0.102 \\
\hline Vocational & $13.66(11.74-15.57)$ & \\
\hline Secondary comprehensive & $14.29(10.67-17.91)$ & \\
\hline Secondary vocational & $14.24(12.22-16.27)$ & \\
\hline Tertiary & $15.07(12.18-17.96)$ & \\
\hline
\end{tabular}

\section{Income per capita/month}

\begin{tabular}{lll}
\hline Up to 1,000 PLN & $18.41(14.65-22.17)$ & 0.333 \\
\hline 1,001 PLN-2,000 PLN & $16.13(14.04-18.23)$ & \\
\hline 2,001 PLN-3,000 PLN & $16.87(14.38-19.36)$ \\
\hline 3,001 PLN-4,000 PLN & $14.42(11.07-17.76)$ \\
\hline 4,001 PLN and above & $14.52(9.35-19.68)$ \\
\hline
\end{tabular}

\section{Number of diagnosed diseases}

\begin{tabular}{lll}
\hline 0 & $2.68(1.29-4.07)$ & $<0.001$ \\
\hline $1-2$ & $9.60(7.83-11.37)$ \\
\hline $3-4$ & $14.85(12.82-16.88)$ \\
\hline 5 and above & $21.71(19.84-23.58)$
\end{tabular}

\section{Physical activity}

\begin{tabular}{lcc}
\hline No & $14.11(12.99-15.22)$ & 0.009 \\
\hline Yes & $17.47(13.93-21.00)$ & \\
\hline
\end{tabular}

also observed in older people and in people with a higher number of diseases. A relationship between physical activity and occurrence of disability was also observed. With regard to people who undertook physical activity in the form of a recreational sport at least 4 times a week, a significantly lower level of disability was recorded compared to those who were less physically active. 


\section{DISCUSSION}

The study of disability is a subject of increasing interest to scientists due to the effects of population ageing in relation to lengthening of professional activity of the elderly, as well as due to the need for planning the sources of health care for the ill and disabled older people.

Along with the increase in life expectancy, the prevalence of chronic diseases has risen, especially in the group of older patients $[22,23]$. Nearly one-quarter of all cases of diseases affects people over the age of 60 [24]. With age, the number of chronic diseases per person increases [25].

In the studied population aged 60-70 years living in the area of south-eastern Poland, a high incidence of chronic diseases was observed. At least one chronic disease was found in $84.10 \%$ of the respondents. Moreover, a very high prevalence of multiple diseases was recorded. As many as $61.00 \%$ of the researched group reported at least 3 chronic diseases suimultaneously. Similar trends regarding multimorbidity of the elderly has been confirmed by studies carried out in other countries [26, 27, 28].

The most common chronic diseases recorded among the studied population living in the area of south-eastern Poland were cardiovascular diseases. The prevalence of these diseases was found in $59.10 \%$ of the respondents, including coronary heart disease which was reported by $23.80 \%$ of those interviewed. These results are consistent with the trend observed globally [29]. The most common chronic diseases of the locomotor system in the study population were degenerative diseases, back pain syndromes and rheumatism. Back pain was found in $51.50 \%$ of the respondents, osteoarthritis $-50.30 \%$, while rheumatic disease - 23.90\%. Many authors indicate a very high prevalence of degenerative diseases of the locomotor system and back pain in the populations of different countries. The prevalence of back pain syndromes in people aged over 60 amounts, on average, to $40-60 \%$. Occurrence of degenerative diseases and pain syndromes of the locomotor system is very high, especially in developed countries [30,31,32]. More and more reports also indicate the increasing incidence of degenerative changes of the spine and back pain in the elderly populations of low- and middle-income countries [33, 34, 35].

Chronic diseases in the elderly lead to a deterioration of their general health condition and reduction of functional capacity [36]. The aggravation of functional capacity leads to difficulty in performing complex, and later on, basic activities of daily living, leading to disability and the dependence of older people [24]. With the increase in life expectancy, it is possible to observed an increase in the prevalence of disability in the elderly population [37].

The measurement and analysis of a human's functioning domains are particularly prone to limitations. It is crucial to identify factors determining the occurrence of disability among the elderly in order to develop preventive means against the limitation of fitness and care-dependence of elderly people, which progresses with age. Appropriate support can be of great significance for the studied population aged 60-70, enabling increased activity and professional efficiency.

The presented study of a representative population aged 60-70 in south-eastern Poland revealed different levels of limitations in everyday functioning in as much as $67.00 \%$ of the studied population, where $46.20 \%$ reported mild disability and $4.50 \%$ moderate disability, and $6.30 \%$ suffered from severe or extreme disability. This is a very large percentage of this age group who should still be professionally active in the future. The mean disability level in the studied Polish population aged $60-70$ was 14.44 . The study revealed a highly statistically significant relationship between the age and the rate of occurrence and level of disability. This has been confirmed by studies carried out in other countries using the WHODAS $[38,39]$ and other questionnaires intended for measuring disability $[40,41]$. As life expectancy is increasing, a quickly growing number of disabled elderly people can be expected in the forthcoming decades. In the conducted study, the highest disability level was observed in the domains related to participation in everyday life, performing complex life activities and mobility. Similarly, Almazán-Isla et al. showed that the level of disability increased with age, especially in terms of mobility and social participation [42]. The disability rate in these domains is increasing the fastest with age, showing that it is becoming the cause of isolation and social exclusion among elderly people, and depression appearing later on [43].

Furthermore, the study revealed that unmarried people demonstrated a significantly higher degree of limitation in everyday functioning than people in a relationship. Converging results were obtained by Chen et al. who showed that disability was associated with old age, single marital status, a sense of isolation and bad mood [44]. Holwerda et al. in a prospective cohort study showed that the feeling of loneliness and social isolation were the main risk factors for increased mortality among older men [45].

The study also revealed that the subjects disability level increases with the rise in the number of diseases suffered. Similar results were obtained by Avalud who concluded that the risk of becoming disabled of a person suffering from 4 chonic diseases is increased 4-fold [46]. Chronic diseases are the leading cause of disability, and the dependence of the elderly, together with low incomes, are the main reason for the use of social welfare benefits [47].

Considering the survey of people aged 60-70 living in south-eastern Poland, it was also observed that people who practiced a recreational sport at least 4 times a week experienced lower levels of disability than those who were less physically active. Similar results were presented by Tak et al. who showed in their meta-analysis that physical activity helps prevent disability and slows the ageing process [14].

No correlation was found between the place of residence (city/town or countryside) and the overall disability level measured by means of the WHODAS 2.0. As a result of the significant migration of the inhabitants of rural areas to cities in the $20^{\text {th }}$ century, and migration from cities to suburban villages in the $21^{\text {st }}$ century, a reduction was observed in the differences between the populations inhabiting these areas. The growth of infrastructure and improvement in access to various services in rural area (e.g. health-care services) has also helped in eliminating the differences between urban and rural inhabitants [48]. In many countries, particularly those that are developing, very high significant differences in disability level were noticed between the inhabitants of urban and rural areas. The inhabitants of rural areas show a significantly higher level of disability, which is connected with restricted access to health care and other services, and difficulties with transport [38].

The studied group did not show any difference in disability level between men and women. Many studies have provided 
evidence which confirms that women demonstrate a higher disability level than men $[39,40]$. According to Gold et al., women live longer with disability [49]. This can be attributed to a longer life expectancy for women and to the female anatomy, e.g. smaller muscle mass and bone density than in men $[50,51,52]$.

\section{CONCLUSIONS}

With reference to the population aged 60-70, living in the area of south-eastern Poland, many health problems were found, that became worse with age. A deteriorating state of health causes limitations in daily functioning, leading to disability and, consequently, reducing the ability to work, early exit from the labour market and the dependence of the elderly. The ageing of Polish population will lead to increased needs in terms of services provided by healthcare institutions and social care, as well as the implementation of prevention programmes, and supporting the functioning of elderly people in different areas of life.

\section{REFERENCES}

1. Kancelaria Senatu. Starzenie się społeczeństwa Polskiego i jego skutki. Biuro Analiz i Dokumentacji. Warszawa, 2011.

2. Börsch-Supan A, Härtl K, Ludwig A. Aging in Europe: Reforms, International Diversification, and Behavioral Reactions. Am Econ Rev. 2014; 104(5): 224-229.

3. European Commission. The 2015 Ageing Report: Economic and budgetary projections for the 28 EU Member States (2013-2060).

4. http://ec.europa.eu/economy_finance/publications/european economy/2015/ee3_en.htm (access: 2016.10.10).

5. EUROSTAT. Population structure and ageing. http://ec.europa.eu/ eurostat/statistics-explained/index.php/Population_structure_and_ ageing (access: 2016.10.10).

6. Commission of the European Communities. Commission Communication. The demographic future of Europe - from challenge to opportunity. Brussels, 2006. http://eur-lex.europa.eu/legal-content/ EN/ALL/?uri=CELEX:52006DC0571 (access: 2016.10.10).

7. United Nations, 2015. World population prospects: the 2015 revision. http://esa.un.org/unpd/wpp/Publications/Files/WPP2015_Volume-IIDemographic-Profiles.pdf (access: 2016.10.10).

8. Błędowski P, Szatur-Jaworska B, Szweda-Lewandowska Z, Kubicki P. Raport na temat sytuacji osób starszych w Polsce. IPiSS. Warszawa, 2012.

9. Cymanow P, Florek-Paszkowska A. Ocena kosztów migracji ludności wiejskiej Karpat w kontekście zarządzania problemowymi obszarami migracyjnymi. Zesz Nauk SGGW, Probl Rol Świat. 2015; 15(30): 26-34.

10. Główny Urząd Statystyczny. Prognoza ludności Polski na lata 2014 2050. GUS. Warszawa, 2014.

11. Główny Urząd Statystyczny. Ludność w wieku 60+. Struktura demograficzna i zdrowie. GUS. Warszawa, 2016.

12. Główny Urząd Statystyczny. Sytuacja demograficzna osób starszych i konsekwencje starzenia się ludności Polski w świetle prognozy na lata 2014-2050. GUS, Warszawa, 2014.

13. Gołata E, Kuropka I. Zmiany demograficzne i ich następstwa dla wybranych obszarów polityki społecznej w dużych miastach w Polsce. Studia Ekonom. 2015; 223: 162-173.

14. Kłos B. Europejskie systemy emerytalne - stan i perspektywy. Analizy BAS. 2011; 5: 1-12.

15. Tak E, Kuiper R, Chorus A, Hopman-Rock M. Prevention of onset and progression of basic ADL disability by physical activity in community dwelling older adults: a meta-analysis. Ageing Res Rev. 2013; 12(1): 329-338.

16. Fraga MF, Esteller M. Epigenetics and aging: the targets and the marks. Trends Genet. 2007; 23: 413-418.

17. Rouquette A, Badley EM, Falissard B, Dub T, Leplege A, Coste J. Moderators, mediators, and bidirectional relationships in the International Classification of Functioning, Disability and Health (ICF) framework: An empirical investigation using a longitudinal design and Structural Equation Modeling (SEM). Soc Sci Med. 2015; 135: 133-142.

18. Officer A, Groce NE. Key concepts in disability. Lancet. 2009; 374: 1795-1796.

19. World Report on Disability; World Health Organization: Geneva, Switzerland, 2011.

20. Hoefsmit N, Houkes I, Nijhuis F. Environmental and personal factors that support early return-to-work: a qualitative study using the ICF as a framework. Work. 2014; 48(2): 203-215.

21. International Classification of Functioning, Disability and Health. WHO, 2001.

22. Üstün TB, Kostanjsek N, Chatterji S, Rehm J. Measuring Health and Disability Manual for WHO Disability Assessment Schedule WHODAS 2.0. WHO, 2010.

23. Orueta JF, Nuño-Solinis R, Mateos M, Vergara I, Grandes G, Esnaola S. Monitoring the prevalence of chronic conditions: which data should we use?. BMC Health Serv Res. 2012; 12: 365.

24. Vasilopoulos T, Kotwal A, Huisingh-Scheetz MJ, Waite LJ, McClintock MK, Dale W. Comorbidity and chronic conditions in the National Social Life, Health and Aging Project (NSHAP), Wave 2. J Gerontol B Psychol Sci Soc Sci. 2014; 69: 154-156.

25. Chatterji S, Byles J, Cutler D, Seeman T, Verdes E. Health, functioning, and disability in older adults-present status and future implications. Lancet. 2015; 385: 563-575.

26. Salisbury C, Johnson L, Purdy S, Valderas JM, Montgomery AA. Epidemiology and impact of multimorbidity in primary care: a retrospective cohort study. Br J Gen Pract. 2011; 61: 12-21.

27. Ahmadi B, Alimohammadian M, Yaseri M, Majidi A, Boreiri M, Islami F et al. Multimorbidity: Epidemiology and Risk Factors in the Golestan Cohort Study, Iran: A Cross-Sectional Analysis. Medicine. 2016; 95(7): e2756.

28. Barnett K, Mercer SW, Norbury M, Watt G, Wyke S, Guthrie B. Epidemiology of multimorbidity and implications for health care, research, and medical education: a cross-sectional study. Lancet. 2012; 380: $37-43$.

29. Foguet-Boreu Q, Violan C, Roso-Llorach A, Rodriguez-Blanco T, Pons-Vigués M, Muñoz-Pérez MA et al. Impact of multimorbidity: acute morbidity, area of residency and use of health services across the life span in a region of south Europe. BMC Fam Pract. 2014; 15: 55.

30. Chronic diseases a vital invesrment - World Health Organization. WHO, 2015. http://www.who.int/chp/chronic_disease_report/ contents/part2.pdf (accessed: 10.10.2016).

31. Musculoskeletal Health in Europe Report v5.0. WHO, 2011. http:// www.eumusc.net/myUploadData/files/Musculoskeletal\%20Health\%20 in\%20Europe\%20Report\%20v5.pdf (accessed: 2016.10.10).

32. Miranda V, de Carvalho V, Machado L, Dias J. Prevalence of chronic musculoskeletal disorders in elderly Brazilians: a systematic review of the literature. BMC Musculoskelet Disord. 2012; 13(1): 82-92.

33. Cecchi F, Debolini P, Ferrucci L, Lova RM, Macchi C, Bandinelli S et al. Epidemiology of back pain in a representative cohort of Italian persons 65 years of age and older: the InCHIANTI study. Spine. 2006; 31(10): 1149-1155.

34. Baek S, Lim J, Paik N, et al. Prevalence of musculoskeletal pain in an elderly Korean population: Results from the Korean Longitudinal Study on Health and Aging (KLoSHA). Arch Gerontol Geriatr. 2016; 51(3): 46-51.

35. Noormohammadpour P, Mansournia MA, Asadi-Lari M, Nourian R, Rostami M, Kordi R. A Subtle Threat to Urban Populations in Developing Countries: Low Back Pain and its Related Risk Factors. Spine. 2016; 41(7):618-627.

36. Stewart Williams J, Ng N, Peltzer K, Yawson A, Biritwum R, Maximova T et al. Risk Factors and Disability Associated with Low Back Pain in Older Adults in Low- and Middle-Income Countries. Results from the WHO Study on Global AGEing and Adult Health (SAGE). PLoS ONE. 2015; 10(6): e0127880.

37. Kadam U, Croft P, for the North Staff ordshire GP Consortium Group. Clinical multimorbidity and physical function in older adults: a record and health status linkage study in general practice. Fam Pract. 2007; 24: 412-419.

38. Ansah JP, Malhotra R, Lew N, Chiu C, Chan A, Bayer S, Matchar DB. Projection of young-old and old-old with functional disability: does accounting for the changing educational composition of the elderly population make a difference? Plos One. 2015; 10(5): e0126471.

39. Adib-Hajbaghery M. Evaluation of old-age disability and related factors among an Iranian elderly population. Eastern Mediterranean Health Journal La Revue de Santé de la Méditerranée orientale. EMHJ. 2011; 17(9): 671-678. 
40. Donmez L, Gokkoca Z, Dedeoglu N. Disability and its effects on quality of life among older people living in Antalya city center, Turkey. Arch Gerontol Geriatr. 2005; 40(2): 213-223.

41. Picavet HS, Hoeymans N. Physical disability in The Netherlands: prevalence, risk groups and time trends. Publ Health. 2002; 116(4): 231-237.

42. Rosa TE, Benicio MH, Latorre M, Mdo R, Ramos LR. Determinant factors of functional status among elderly. Rev Saude Publica. 2003; 37(1): 40-48.

43. Almazán-Isla J, Comín-Comín M, Damián J, Alcalde-Cabero E, Ruiz C, Franco E, Martín G, Larrosa-Montañés LA, de Pedro-Cuesta J; DISCAP-ARAGON Research Group. Analysis of disability using WHODAS 2.0 among the middle-aged and elderly in Cinco Villas, Spain. Disabil Health J. 2014; 7(1): 78-87.

44. Verhaak P, Dekker J, de Waal M, van Marwijk H, Comijs H. Depression, disability and somatic diseases among elderly. J Affect Dis. 2014; 167: 187-191.

45. Chen W, Fang Y, Mao F, Hao S, Chen J, Yuan M et al. Assessment of Disability among the Elderly in Xiamen of China: A Representative Sample Survey of 14,292 Older Adults. PLoS One. 2015; 10(6): e0131014.

46. Holwerda TJ, Beekman AT, Deeg DJ, Stek ML, van Tilburg TG, Visser $\mathrm{PJ}$, et al. Increased risk of mortality associated with social isolation in older men: only when feeling lonely? Results from the Amsterdam Study of the Elderly (AMSTEL). Psychol Med. 2012; 42(4): 843-853.
47. Avlund K. Disability in old age: Longitudinal population-based studies of the disablement process. Den Med J. 2004; 51(4): 315-349.

48. Burzynska M, Bryla M, Bryla P, Maniecka-Bryla I. Factors determining the use of social support services among elderly people living in a city environment in Poland. Health Soc Care Community. 2016; 24(6): $758-768$.

49. Główny Urząd Statystyczny. Dochody i warunki życia ludności Polski (raport z badania EU-SILC 2014). GUS. Warszawa, 2015.

50. Gold CH, Malmberg B, McClearn GE, Pedersen NL, Berg S. Gender and health: a study of older unlike-sex twins. J Gerontol B Psychol Sci Soc Sci. 2002; 57(3): 168-176.

51. Janssen I, Heymsfield S, Ross R. Low Relative Skeletal Muscle Mass (Sarcopenia) in Older Persons Is Associated with Functional Impairment and Physical Disability. J Am Geriatr Soc. 2002; 50(5): 889-896.

52. Ferrucci L, Baroni M, Ranchelli A, Ruggiero C. Interaction Between Bone and Muscle in Older Persons with Mobility Limitations. Current pharmaceutical design. 2014; 20(19): 3178-3197.

53. Suuronen J, Sjöblom S, Rikkonen T, Honkanen R, Koivumaa-Honkanen $\mathrm{H}$, Króger $\mathrm{H}$, et al. The relationship of severe health disorders with bone loss, grip strength, and mobility in postmenopausal women - a 15-year follow-up study. Disability \& Rehabilitation. 2016; 38(14): 1407-1414. 